\title{
Ventricular myocyte injury by high-intensity electric field: Effect of pulse duration
}

\author{
Luiza N. S. Prado ${ }^{1}$, Jair T. Goulart ${ }^{1}$, Marcelo Zoccoler ${ }^{1}$ and Pedro X. Oliveira ${ }^{1,2}$ \\ ${ }^{1}$ Department of Biomedical Engineering, School of Electrical and Computer Engineering, University of Campinas, São Paulo, \\ Brazil \\ ${ }^{2}$ Center for Biomedical Engineering, University of Campinas, Campinas, São Paulo, Brazil
}

\begin{abstract}
Although high-intensity electric fields (HEF) application is currently the only effective therapy available to terminate ventricular fibrillation, it may cause injury to cardiac cells. In this study we determined the relation between HEF pulse length and cardiomyocyte lethal injury. We obtained lethality curves by survival analysis, which were used to determine the value of HEF necessary to kill $50 \%$ of cells $\left(\mathrm{E}_{50}\right)$ and plotted a strength-duration $(\mathrm{SxD})$ curve for lethality with 10 different durations: $0.1,0.2,0.5,1,3,5,10,20,35$ and $70 \mathrm{~ms}$. For the same durations we also obtained an SxD curve for excitation and established an indicator for stimulatory safeness (stimulation safety factor $\mathrm{SSF}$ ) as the ratio between the SxD curve for lethality and one for excitation. We found that the lower the pulse duration, the higher the HEF intensity required to cell death. Contrary to expectations, the highest SSF value does not correspond to the lowest pulse duration but to the one of $0.5 \mathrm{~ms}$. As defibrillation threshold has been described as duration-dependent, our results imply that the use of shorter stimulus duration - instead of the one typically used in the clinic (10 ms) - might increase defibrillation safeness.
\end{abstract}

Key words: Defibrillator-like shocks - Lethality curve - Strength-duration curve - Stimulation safety factor - Defibrillation

\section{Introduction}

The cardiac pumping function efficiency depends on the heart contractile activity synchronism. Arrhythmias affecting this synchronism, such as in ventricular fibrillation cases (Roger et al. 2012), may lead to death. The only effective therapy to terminate those arrhythmias is delivering highintensity electric fields (HEF) to cardiac tissue. This method has been clinically used for decades, but the HEF necessary to stimulate a sufficient amount of cardiac cells may cause several injuries to the myocytes due to the generation of nonuniform potential gradients - some regions of the heart may be exposed to HEF higher than $100 \mathrm{~V} / \mathrm{cm}$ (Yabe et al. 1990). This may lead to depression of electrical and contractile func-

Correspondence to: Pedro Xavier de Oliveira, Department of Biomedical Engineering, School of Electrical and Computer Engineering, University of Campinas, Av. Albert Einstein, 400, Campinas, São Paulo, Brazil

E-mail: pedrox@ceb.unicamp.br tion and even to cell death (Peleška et al. 1963; Jones et al. 1978; Jones and Jones 1980, 1984; Tung 1996; Nikolski and Efimov 2005; Fedorov et al. 2008; Oliveira et al. 2008).

The cell injuries associated to defibrillator-like shocks are probably caused by electroporation: formation of hydrophilic pores in the cell membrane as a result of HEF application (Jones et al. 1987; Weaver 1994; Tung 1996; Krauthamer and Jones 1997; Ivorra 2010; Klauke et al. 2010; Miklavčič et al. 2010).

Cell excitability and cell membrane electroporation are both dependent on applied stimulus strength and duration (Ivorra 2010). The external field applied on the capacitivelike cell membrane induces an electric potential gradient over the external surface of the membrane, depolarizing one side of the cell while hyperpolarizing the other side (Klee and Plonsey 1976; Kinosita Jr. et al. 1988). However, cell excitability requires the opening of a certain amount of ion selective voltage-dependent channels (Bers 2001), which raises the electrical potential nearby, hence, increasing the probability for more channels opening. This eventually turns 
into a chain reaction that elevates the potential throughout the entire surface. On the other hand, membrane electroporation generates nonselective pores in membrane regions where the magnitude of the transmembrane potential variation $\left(\Delta V_{\mathrm{m}}\right)$ induced by electric field $(\mathrm{E})$ reaches a critical value (Ivorra 2010). Furthermore, electroporation is a selflimiting phenomenon, since pores formation restricts $\Delta \mathrm{V}_{\mathrm{m}}$. Therefore, the study of the effect of stimulatory parameters, such as stimulus strength and duration, seems to be mandatory to develop more effective and safe cardiac cells stimulation procedures. These parameters are well established for stimulation but not for HEF as those expected during defibrillation.

Our aim is to study the HEF strength and duration necessary to kill $50 \%$ of cells $\left(\mathrm{E}_{50}\right)$ and its relations with E threshold that evokes cell contraction $\left(\mathrm{E}_{\mathrm{T}}\right)$. We used the stimulation safety factor (SSF), i.e., the ratio between $\mathrm{E}_{50}$ and $\mathrm{E}_{\mathrm{T}}$, to evaluate this relationship. SSF was calculated as the "safety factor" (Oliveira et al. 2008) and the "threshold factor" (Reilly et al. 2009) but considering as reference the $\mathrm{E}_{\mathrm{T}}$ of each cell instead of a reference-case neuron. SSF gives a numerical rating that provides a measure of effectiveness to any form of electrical stimulation. A higher SSF would mean a safer stimulation procedure.

\section{Materials and Methods}

\section{Isolated ventricular myocytes}

Ventricular myocytes were isolated from adult male Wistar rat hearts by coronary perfusion with collagenase I (0.4-0.5 $\mathrm{mg} / \mathrm{ml}$; Worthington Biochem., Lakewood, NJ, USA) in Langendorff system. Briefly, the left ventricle was separated from the heart and the isolated myocytes suspension was obtained by mechanical dissociation (Penna and Bassani 2010). Cells were stored at $4^{\circ} \mathrm{C}$ and used within $6 \mathrm{~h}$ after isolation (Louch et al. 2011).

The experimental protocol was approved by the Institutional Committee for Ethics in Animal Research (IB/ UNICAMP, No. 2587-1(F) and 2942-1(D)).

The isolated myocytes were plated in a perfusion chamber where we placed a pair of platinum electrodes, $0.75 \mathrm{~cm}$ apart, along the lateral walls at the bottom of the chamber and parallel to the solution flow direction. The perfusion chamber (developed by CEB/UNICAMP; Campinas, SP, Brazil) is able to supply a laminar flow of solution in a constant volume, allowing electric field estimation with $2 \%$ of precision (Oliveira et al. 2008). Cells were perfused with Tyrode's solution (composition (in mM): $140 \mathrm{NaCl}, 6 \mathrm{KCl}, 1.5 \mathrm{MgCl}_{2}, 5 \mathrm{HEPES}$, $1 \mathrm{CaCl}_{2}, 11$ glucose, $\mathrm{pH} 7.4$ ) at $23 \pm 2{ }^{\circ} \mathrm{C}$.

All procedures were performed only in rod-shaped cells with clear cross striations responding to electrical stimula- tion by performing contractions. Also, the cells had to be located at least $2 \mathrm{~mm}$ far from the electrodes (Oliveira et al. 2008), distant from neighbor cells, and parallel to the applied E lines $\left( \pm 5^{\circ}\right)$. We used one cell per chamber.

\section{Cell pacing and high intensity electric field stimulation}

A low-intensity voltage stimulator (LIS; developed by CEB/ UNICAMP; Campinas, SP, Brazil) was used to apply symmetric biphasic or monophasic voltage pulses (waveforms in Figure 1) above threshold, strong enough to evoke cell contraction. Pulse intensity was gradually decreased until the contraction stopped. We considered $\mathrm{E}_{\mathrm{T}}$ as the amplitude of the positive phase from the last pulse before cell contraction stopped. $\mathrm{E}_{\mathrm{T}}$ was first obtained for biphasic pulses ( $5 \mathrm{~ms}$ each semi cycle) at $0.5 \mathrm{~Hz}$ for all cells $\left(\mathrm{E}_{\mathrm{T}-5 \mathrm{~ms}}\right)$. They were paced for $5 \mathrm{~min}$ at $0.5 \mathrm{~Hz}$ with symmetric biphasic pulses $20 \%$ above threshold before any procedure. The pulses were constantly monitored by an oscilloscope (Agilent DSO3062A; Tektronix Inc., Beaverton, OR, USA). A schematic representation of our setup is presented in Figure 1.

In order to perform $\mathrm{SxD}$ curves, the cells were divided into 11 groups: 10 of them, each with a specific pulse length $(0.1,0.2,0.5,1,3,5,10,20,35$ and $70 \mathrm{~ms})$, were used to build an excitation $\mathrm{SxD}$ curve (biphasic pulses) and the lethality $\mathrm{SxD}$ curve in a paired fashion, while the last group was exclusively used to generate two-paired excitation $\mathrm{SxD}$ curves (monophasic and biphasic pulses, all durations). Regarding the 10 groups, we determined $\mathrm{E}_{\mathrm{T}}$ in the same way we did for $\mathrm{E}_{\mathrm{T}-5 \mathrm{~ms}}$ : using $0.5 \mathrm{~Hz}$ symmetric biphasic voltage pulses, but with the specific pulse length of each group ( $\mathrm{E}_{\mathrm{T}-\mathrm{SPL}}$ ). Then, the chosen cell was subjected to a single monophasic HEF shock (Figure 1; pulse duration was group specific and pulse magnitude was defined as $\mathrm{E}_{\mathrm{T}-\mathrm{SPL}}$ multiplied by a factor) by switching to a high-intensity voltage stimulator (HIS; developed by CEB/UNICAMP; Campinas, SP, Brazil) synchronized with LIS (Figure 1). After a 3-10 min resting period, pacing was reestablished and a new HEF shock was delivered. The procedure was repeated each time with a stronger shock until cell death which was identified by the development of sustained hypercontracture and the release of intracellular material, accompanied by irreversible loss of responsiveness to electric stimulation and lack of discernible internal structure (Oliveira et al. 2008). The data obtained from this protocol (the greatest non-lethal HEF and the HEF lethal) were used as input for a survival analysis (Kleinbaum 1996) whose output was a data set containing the probability of cell death at different HEF intensities. The outputted data set was used to create the lethality curves, i.e., curves that relate the HEF intensity and the probability of cell death.

In the last group of cells, we performed an entire excitation $\mathrm{SxD}$ curve for each cell using symmetric biphasic and 


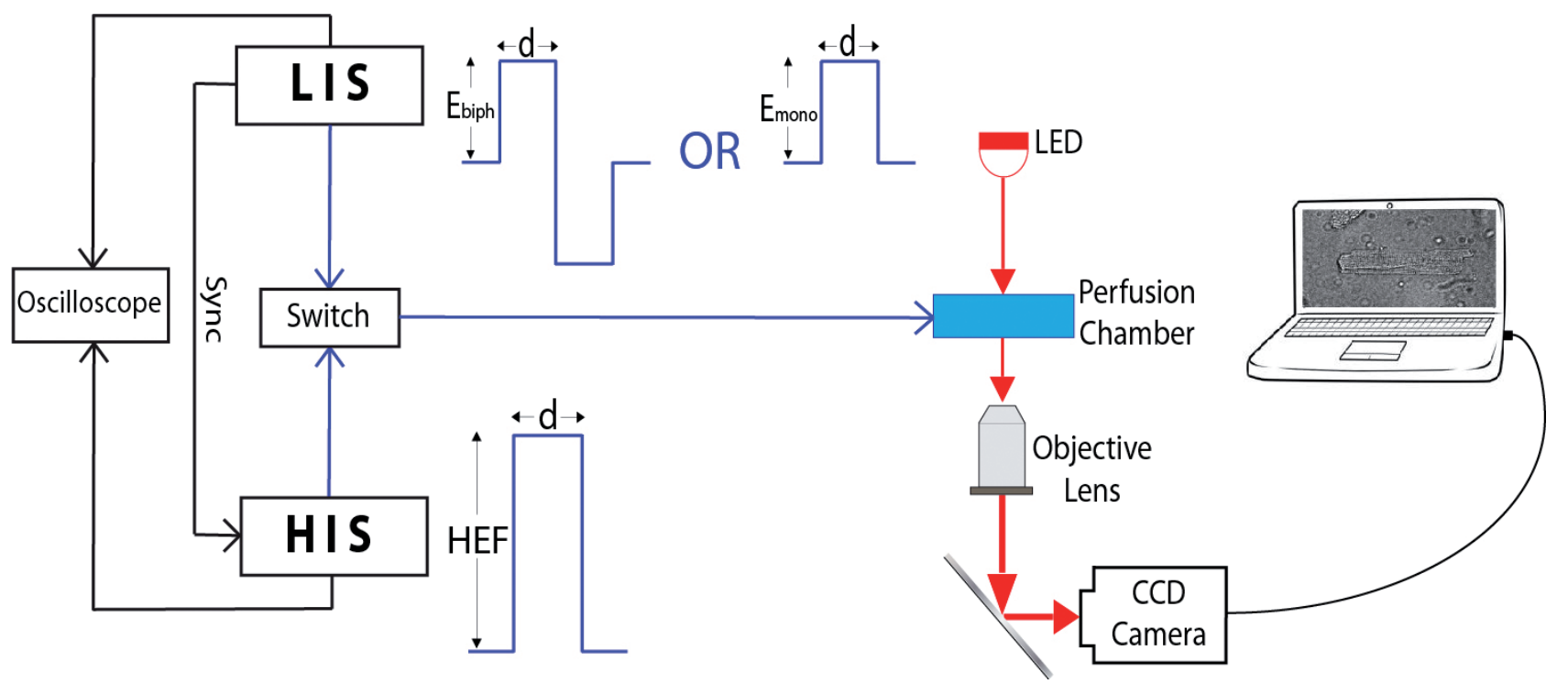

Figure 1. Schematic representation of the experimental setup. Low intensity voltage-stimulator (LIS) used for cell pacing: symmetric biphasic voltage pulses $\left(\mathrm{E}_{\text {biph }}\right)$ or monophasic voltage pulses $\left(\mathrm{E}_{\text {mono }}\right)$ with different durations $(\mathrm{d})$. High intensity voltage-stimulator (HIS) used for defibrillator-like shocks synchronized (sync) by LIS: high intensity electric field (HEF) pulse with different d. Switch for stimulator selection. Oscilloscope used for pulse monitoring. Perfusion chamber used for cell stimulation. Imaging system: LED, objective lens and CCD camera connected to a computer.

monophasic voltage pulses $(0.5 \mathrm{~Hz})$. $\mathrm{E}_{\mathrm{T}}$ for biphasic pulses $\left(\mathrm{E}_{\mathrm{T}-b i p h}\right)$ and $\mathrm{E}_{\mathrm{T}}$ for monophasic pulses ( $\left.\mathrm{E}_{\mathrm{T}-\mathrm{mono}}\right)$ were evaluated by the same procedure done for $\mathrm{E}_{\mathrm{T}-5 \mathrm{~ms}}$. No HEF pulses were applied to this group.

\section{Statistical analysis}

The SxD curves for excitation were fitted by the WeissLapicque equation

$$
Y=E_{r h}\left(1+\frac{C_{r}}{d}\right)
$$

where $\mathrm{Y}$ is the $\mathrm{E}$ intensity correspondent to a pulse duration $\mathrm{d}, \mathrm{E}_{\mathrm{rh}}$ is the rheobase (value of $\mathrm{E}$ correspondent to an infinite $\mathrm{d}$ ), and $\mathrm{C}_{\mathrm{r}}$ is the chronaxie (pulse duration correspondent to $\mathrm{Y}=2 \mathrm{E}_{\mathrm{rh}}$ ). The correlation between all $\mathrm{SxD}$ curves for excitation ( $\mathrm{E}_{\mathrm{T}-\mathrm{biph}}, \mathrm{E}_{\mathrm{T}-\mathrm{mono}}$ and $\mathrm{E}_{\mathrm{T}-\mathrm{SPL}}$ ) was tested by linear regression.

The lethality curves obtained by the survival analysis, as described above, were fitted through the following equation:

$$
P=\frac{1}{1+\left(\frac{E_{50}}{E}\right)^{n}}
$$

where $\mathrm{P}$ is the probability of lethality, $\mathrm{E}_{50}$ is the value of E correspondent to $\mathrm{P}=0.5$ and $\mathrm{n}$ is the Hill coefficient $\left(\mathrm{R}^{2}\right.$ $>0.90$ in all cases). The $\mathrm{E}_{50}$ and $\mathrm{n}$ fitting parameters of the lethality curves were compared by $95 \%$ confidence interval (CI95) overlapping.

The $\mathrm{SxD}$ curve for lethality was obtained plotting the $\mathrm{E}_{50}$ from each lethality curve and fitted by a modified version of the equation described by Krassowska et al. $\left(\mathrm{Y}=\mathrm{Kd}^{\mathrm{A}}\right.$, Krassowska et al. 2003):

$$
E_{50}=K d^{A}+B
$$

where $\mathrm{E}_{50}$, obtained by Equation 2, is the intensity of electric field required to kill $50 \%$ of cells, and d is pulse duration. $\mathrm{K}$, $\mathrm{A}$ and $\mathrm{B}$ are adjustable parameters.

The SSF curve was plotted dividing the Eq. 3 by Eq. 1:

$$
S S F=\frac{K d^{A}+B}{E_{r h}\left(1+\frac{C_{r}}{d}\right)}
$$

where the $\mathrm{K}, \mathrm{A}$ and $\mathrm{B}$ values were taken from the best fit of these parameters in Eq. 3, $\mathrm{E}_{\mathrm{rh}}$ and $\mathrm{C}_{\mathrm{r}}$ values were taken from the best fit of Eq. 1 using $\mathrm{E}_{\mathrm{T}-\mathrm{SPL}}$, and $\mathrm{d}$ is the pulse length.

Also, we used ratios E/ $\mathrm{E}_{\mathrm{T}-\mathrm{SPL}}$ as inputs (the greatest $\mathrm{E}$ non-lethal/E $\mathrm{E}_{\mathrm{T}-\mathrm{SPL}}$ and the $\mathrm{E}$ lethal/ $\mathrm{E}_{\mathrm{T}-\mathrm{SPL}}$ ) to run a survival analysis and create normalized lethality curves. Thus, similar to the procedure by which we used $\mathrm{E}_{50}$ to create the $\mathrm{SxD}$ curve for lethality, we plotted the ratios associated to $50 \%$ of cell death $\left(\mathrm{E} / \mathrm{E}_{\mathrm{T}-\mathrm{SPL}}\right)_{50}$, together with the SSF curve 
generated from Eq. 4. Point deviation from the SSF curve model was evaluated by the Runs test.

Data are presented as means accompanied by the standard error except for $\mathrm{E}_{50}$ and $\mathrm{n}$ fitting parameter, which are presented as means and CI95. Cell major axis (length), minor axis (width) and $\mathrm{E}_{\mathrm{T}-5 \mathrm{~ms}}$ were compared between all groups by the one-way ANOVA test. Lethality curves were compared using the Mantel-Cox test. Statistical significance was considered to occur when $p \leq 0.05$. All tests and analyses were made using the software Prism 5.03 (GraphPad Software, San Diego, USA).

\section{Results}

\section{Comparison between cell experimental groups}

$\mathrm{E}_{\mathrm{T}-5 \mathrm{~ms}}$, width and length values are presented on Table 1. Values of $\mathrm{E}_{\mathrm{T}-5 \mathrm{~ms}}$ were not significantly different; this shows that the cells from all groups could probably be comparable in terms of excitability. Width and length values were also not significantly different. The values found for those variables were similar to those previously found in the literature (Bassani et al. 2006; Goulart et al. 2012).

\section{Excitation SxD curve}

Table 2 shows the data for excitation $\mathrm{SxD}$ curves (Figure $\left.2 \mathrm{~A} ; \mathrm{E}_{\mathrm{T}-\mathrm{SPL}} ; \mathrm{E}_{\mathrm{T} \text {-biph }} ; \mathrm{E}_{\mathrm{T} \text {-mono }}\right)$. All the $\mathrm{SxD}$ curves are linearly related with $p<0.0001$ and $\mathrm{R}^{2}>0.99$ (Figure 2B,C and D).

Table 1. Cell parameters

\begin{tabular}{ccccc}
\hline $\begin{array}{c}\text { Pulse } \\
\text { length }(\mathrm{ms})\end{array}$ & $\mathrm{N}$ & $\begin{array}{c}\mathrm{E}_{\mathrm{T}-5 \mathrm{~ms}} \\
(\mathrm{~V} / \mathrm{cm})\end{array}$ & $\begin{array}{c}\text { Width } \\
(\mu \mathrm{m})\end{array}$ & $\begin{array}{c}\text { Length } \\
(\mu \mathrm{m})\end{array}$ \\
\hline 0.1 & 12 & $2.94 \pm 0.09$ & $28.2 \pm 1.19$ & $126.2 \pm 3.97$ \\
0.2 & 7 & $3.06 \pm 0.06$ & $28.56 \pm 2.06$ & $138.5 \pm 4.03$ \\
0.5 & 11 & $3.11 \pm 0.08$ & $30.14 \pm 1.29$ & $117.3 \pm 4.68$ \\
1 & 10 & $3.00 \pm 0.10$ & $29.25 \pm 1.18$ & $128.1 \pm 3.51$ \\
3 & 13 & $3.09 \pm 0.12$ & $28.68 \pm 1.55$ & $119.0 \pm 4.00$ \\
5 & 15 & $3.33 \pm 0.09$ & $28.52 \pm 1.52$ & $122.0 \pm 3.51$ \\
10 & 13 & $3.26 \pm 0.12$ & $29.09 \pm 1.75$ & $120.9 \pm 4.63$ \\
20 & 11 & $3.08 \pm 0.10$ & $30.69 \pm 1.95$ & $122.6 \pm 5.19$ \\
35 & 16 & $3.18 \pm 0.07$ & $28.29 \pm 0.99$ & $124.8 \pm 2.65$ \\
70 & 10 & $3.29 \pm 0.13$ & $30.15 \pm 2.01$ & $123.8 \pm 4.97$ \\
\hline Mono\&Biph & 13 & $3.42 \pm 0.16$ & $30.38 \pm 2.14$ & $131.8 \pm 4.37$
\end{tabular}

Mean \pm standard error of $\mathrm{E}_{\mathrm{T}-5 \mathrm{~ms}}$ (electric filed threshold to stimulate cells using $5 \mathrm{~ms}$ long biphasic pulses), width and length values for all groups analyzed (each with a specific pulse length for defibrillatorlike shocks). There was no significant difference in any case (one-way ANOVA test). Mono\&Biph, all durations; N, number of cells.

\section{Lethality curves}

Curves relating probability of lethality and intensity of HEF (Figure 3A,B and C) were different for each stimulus duration ( $p<0.0001$; Mantel-Cox test) and showed that the longer the pulse duration, the lower the HEF intensity required to cell death. $\mathrm{E}_{50}$ and $\mathrm{n}$ values are presented in Table 3. $E_{50}$ was different among all groups except between 35 and $70 \mathrm{~ms}$; $n$ was different only for $20 \mathrm{~ms}$ compared to $0.1,3,5,10,35$ and $70 \mathrm{~ms}$.

\section{Lethality SxD curve}

From the $\mathrm{E}_{50}$ values obtained by the sigmoid fitting of lethality curves (Table 3 ), we could determine the SxD curve for lethality (Figure 3D). Values obtained for parameters K, $\mathrm{A}$ and $\mathrm{B}$ were $125.1 \pm 3.89,-0.53 \pm 0.01$ and $38.84 \pm 2.70$, respectively $\left(R^{2}=0.99\right)$.

\section{Stimulation safety factor}

SSF is presented in Figure 4 and Table 4 . The normalized lethality curves are shown in Figure 4A,B and C. All curves were different ( $p<0.0001$; Mantel-Cox test), however, (E/ $\left.\mathrm{E}_{\mathrm{T}-\mathrm{SPL}}\right)_{50}$ is not different between $0.1 \mathrm{~ms}$ compared to 35 and $70 \mathrm{~ms} ; 0.2 \mathrm{~ms}$ compared to 5,10 and $20 \mathrm{~ms} ; 1 \mathrm{~ms}$ compared to $3 \mathrm{~ms} ; 5 \mathrm{~ms}$ compared to 10 and $20 \mathrm{~ms} ; 10 \mathrm{~ms}$ compared to $20 \mathrm{~ms} ; 20 \mathrm{~ms}$ compared to $70 \mathrm{~ms}$; and $35 \mathrm{~ms}$ compared to $70 \mathrm{~ms} ; n$ was not different in any group.

Table 2. Excitation curves parameters

\begin{tabular}{cccc}
\hline $\begin{array}{c}\text { Pulse } \\
\text { length }(\mathrm{ms})\end{array}$ & $\begin{array}{c}\mathrm{E}_{\mathrm{T}-\mathrm{SPL}} \\
(\mathrm{V} / \mathrm{cm})\end{array}$ & $\begin{array}{c}\mathrm{E}_{\mathrm{T}-b i p h} \\
(\mathrm{~V} / \mathrm{cm})\end{array}$ & $\begin{array}{c}\mathrm{E}_{\mathrm{T}-\mathrm{mono}} \\
(\mathrm{V} / \mathrm{cm})\end{array}$ \\
\hline 0.1 & $22.57 \pm 1.08(\mathrm{~N}=12)$ & $21.36 \pm 1.07$ & $26.14 \pm 1.33$ \\
0.2 & $11.93 \pm 0.43(\mathrm{~N}=7)$ & $11.64 \pm 0.54$ & $15.56 \pm 0.70$ \\
0.5 & $6.41 \pm 0.37(\mathrm{~N}=11)$ & $6.68 \pm 0.36$ & $8.90 \pm 0.45$ \\
1 & $4.42 \pm 0.14(\mathrm{~N}=10)$ & $4.93 \pm 0.26$ & $6.94 \pm 0.37$ \\
3 & $3.52 \pm 0.15(\mathrm{~N}=13)$ & $3.65 \pm 0.18$ & $5.34 \pm 0.31$ \\
5 & $3.33 \pm 0.09(\mathrm{~N}=15)$ & $3.35 \pm 0.16$ & $4.95 \pm 0.30$ \\
10 & $2.88 \pm 0.13(\mathrm{~N}=13)$ & $2.86 \pm 0.22$ & $4.35 \pm 0.35$ \\
20 & $2.61 \pm 0.07(\mathrm{~N}=11)$ & $2.67 \pm 0.20$ & $4.31 \pm 0.35$ \\
35 & $2.43 \pm 0.05(\mathrm{~N}=16)$ & $2.44 \pm 0.21$ & $3.69 \pm 0.32$ \\
50 & - & $2.25 \pm 0.19$ & $3.43 \pm 0.27$ \\
70 & $2.45 \pm 0.09(\mathrm{~N}=10)$ & - & - \\
\hline
\end{tabular}

Mean \pm standard error of $\mathrm{E}_{\mathrm{T}-\mathrm{SPL}}, \mathrm{E}_{\mathrm{T}-\text { biph }}(\mathrm{N}=13)$ and $\mathrm{E}_{\mathrm{T}-\mathrm{mono}}$ $(\mathrm{N}=13) . \mathrm{E}_{\mathrm{T}-\mathrm{SPL}}$, electric field threshold $\left(\mathrm{E}_{\mathrm{T}}\right)$ to stimulate cells using biphasic pulses with the specific pulse length of each group; $\mathrm{E}_{\mathrm{T} \text {-biph }}, \mathrm{E}_{\mathrm{T}}$ to stimulate cells using biphasic pulses; $\mathrm{E}_{\mathrm{T} \text {-mono, }} \mathrm{E}_{\mathrm{T}}$ to stimulate cells using monophasic pulses; $\mathrm{E}_{\mathrm{T}-\mathrm{SPL}}$ was evaluated in the groups of cells submitted to defibrillator-like shocks while $\mathrm{E}_{\mathrm{T}}$ biph and $\mathrm{E}_{\mathrm{T} \text {-mono }}$ were pared and assessed in a group that did not received defibrillator-like shocks. $\mathrm{N}$, number of cells. 


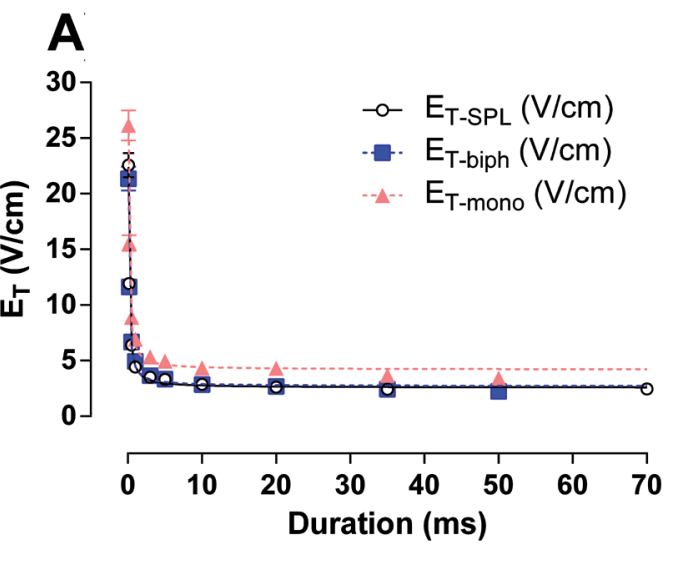

\section{C}

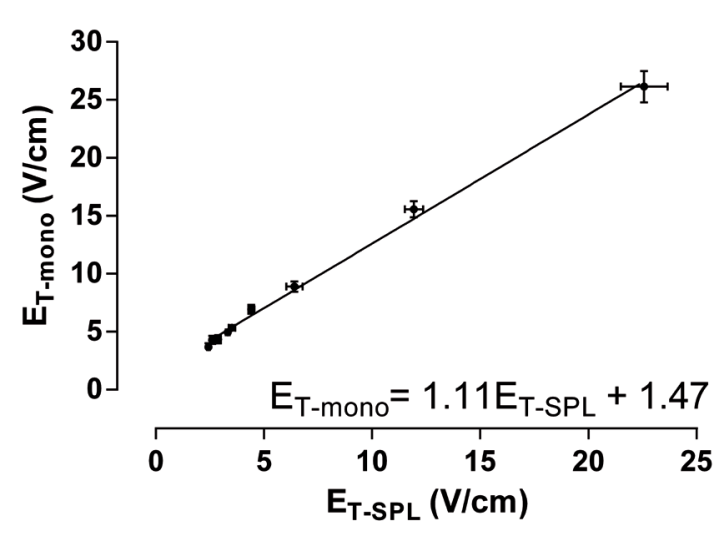

B

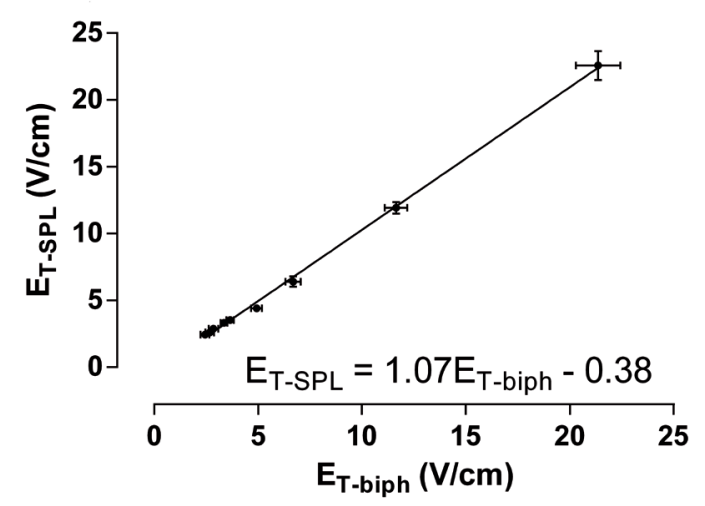

D

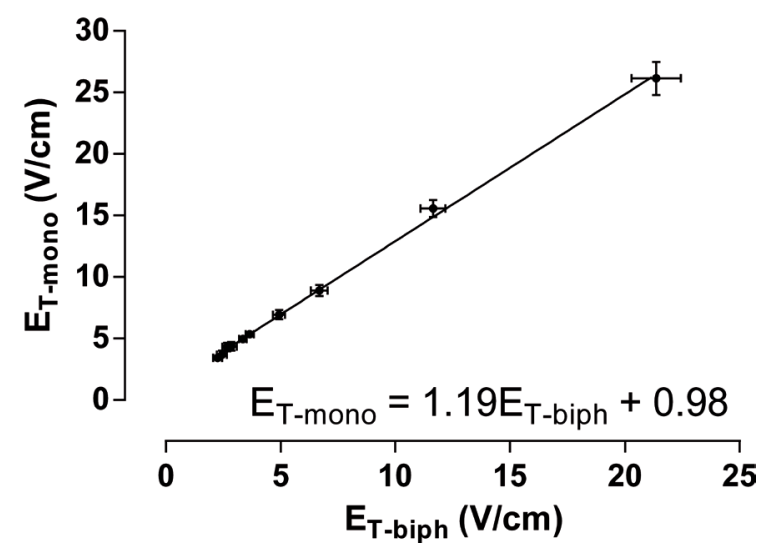

Figure 2. Strength-duration curves $(\mathrm{SxD})$ for excitation and their linear correlation. A. SxD curves for $\mathrm{E}_{\mathrm{T}-\mathrm{SPL}}\left(\mathrm{E}_{\mathrm{rh}}=2.58 \pm 0.14 \mathrm{~V} / \mathrm{cm}\right.$; $\left.\mathrm{C}_{\mathrm{r}}=0.77 \pm 0.05 \mathrm{~ms} ; \mathrm{R}^{2}=0.96\right), \mathrm{E}_{\mathrm{T}-\text { biph }}\left(\mathrm{E}_{\mathrm{rh}}=2.70 \pm 0.16 ; \mathrm{C}_{\mathrm{r}}=0.69 \pm 0.05 ; \mathrm{R}^{2}=0.94\right)$ and $\mathrm{E}_{\mathrm{T}-\mathrm{mono}}\left(\mathrm{E}_{\mathrm{rh}}=4.21 \pm 0.21 ; \mathrm{C}_{\mathrm{r}}=0.53 \pm 0.03 ;\right.$ $\left.\mathrm{R}^{2}=0.92\right)$ as described in Table 2. B. C. D. Linear correlation between each pair of SxD curve $\left(p<0.0001\right.$ and $\mathrm{R}^{2}>0.99$ in all cases). Symbols indicate means and vertical and horizontal bars indicate standard errors.

Table 3. Lethality curves fittings parameters

\begin{tabular}{cccccc}
\hline \multirow{2}{*}{$\begin{array}{c}\text { Pulse length } \\
(\mathrm{ms})\end{array}$} & \multicolumn{2}{c}{$\mathrm{E}_{50}(\mathrm{~V} / \mathrm{cm})$} & & \multicolumn{2}{c}{$\mathrm{n}$} \\
\cline { 2 - 3 } \cline { 5 - 6 } & Mean & CI95 & & Mean & CI95 \\
\hline $0.1(\mathrm{~N}=12)$ & 474.8 & 461.4 to 488.1 & & 8.2 & 6.4 to 10.03 \\
$0.2(\mathrm{~N}=7)$ & 332.3 & 315.7 to 348.9 & & 10.1 & 4.0 to 16.2 \\
$0.5(\mathrm{~N}=11)$ & 242 & 238.0 to 246.1 & & 12.9 & 9.8 to 16.0 \\
$1(\mathrm{~N}=10)$ & 148.2 & 145.2 to 151.2 & & 13.0 & 9.3 to 16.8 \\
$3(\mathrm{~N}=13)$ & 108.8 & 105.8 to 111.9 & & 8.3 & 6.5 to 10.2 \\
$5(\mathrm{~N}=15)$ & 90.7 & 88.6 to 92.8 & & 7.4 & 6.1 to 8.7 \\
$10(\mathrm{~N}=13)$ & 76.6 & 73.6 to 79.6 & & 7.7 & 5.6 to 9.8 \\
$20(\mathrm{~N}=11)$ & 66.2 & 65.1 to 67.3 & & 16.6 & 11.3 to 21.8 \\
$35(\mathrm{~N}=16)$ & 53.6 & 50.73 to 56.4 & & 7.7 & 4.9 to 10.4 \\
$70(\mathrm{~N}=10)$ & 53.7 & 51.2 to 56.1 & & 7.4 & 4.9 to 9.9 \\
\hline
\end{tabular}

Mean and 95\% confidence intervals (CI95) for electric field intensity correspondent to probability of death equal to $50 \%\left(\mathrm{E}_{50}\right)$, and the respective Hill coefficient (n). N, number of cells.
Table 4. Normalized lethality curves fittings parameters

\begin{tabular}{cccccc}
\hline \multirow{2}{*}{$\begin{array}{c}\text { Pulse length } \\
(\mathrm{ms})\end{array}$} & \multicolumn{2}{c}{ SSF: (E/ $\left.\mathrm{E}_{\mathrm{T}-\mathrm{SPL}}\right)_{50}$} & & \multicolumn{2}{c}{$\mathrm{n}$} \\
\cline { 2 - 3 } \cline { 5 - 6 } \cline { 5 - 6 } & Mean & CI95 & & Mean & CI95 \\
\hline $0.1(\mathrm{~N}=12)$ & 20.5 & 19.6 to 21.3 & & 8.2 & 5.7 to 10.7 \\
$0.2(\mathrm{~N}=7)$ & 25.6 & 23.6 to 27.5 & & 20.9 & -28.2 to 69.9 \\
$0.5(\mathrm{~N}=11)$ & 38.9 & 36.8 to 41.0 & & 7.8 & 4.9 to 10.8 \\
$1(\mathrm{~N}=10)$ & 32.5 & 30.9 to 34.1 & & 11.3 & 5.9 to 16.7 \\
$3(\mathrm{~N}=13)$ & 30.5 & 28.9 to 32.0 & & 7.0 & 4.8 to 9.7 \\
$5(\mathrm{~N}=15)$ & 25.8 & 24.2 to 27.4 & & 8.4 & 4.4 to 12.5 \\
$10(\mathrm{~N}=13)$ & 25.6 & 23.9 to 27.3 & & 26.3 & -40.3 to 92.8 \\
$20(\mathrm{~N}=11)$ & 23.4 & 22.5 to 24.3 & & 11.7 & 7.4 to 15.9 \\
$35(\mathrm{~N}=16)$ & 20.8 & 19.5 to 22.1 & & 8.2 & 4.5 to 11.9 \\
$70(\mathrm{~N}=10)$ & 20.9 & 19.1 to 22.6 & & 17.6 & -10.8 to 46.1 \\
\hline
\end{tabular}

Mean and 95\% confidence interval (CI95) for normalized electric field intensity correspondent to probability of death equal to $50 \%$ $\left(\mathrm{E} / \mathrm{E}_{\mathrm{T}-\mathrm{SPL}}\right)_{50}$, i.e., the stimulation safety factor (SSF) and the respective Hill coefficient (n). N, number of cells. 
A

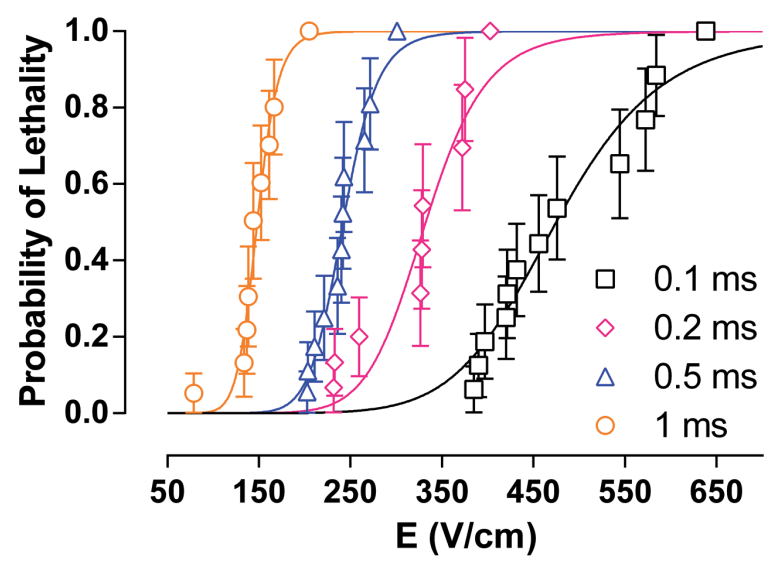

C

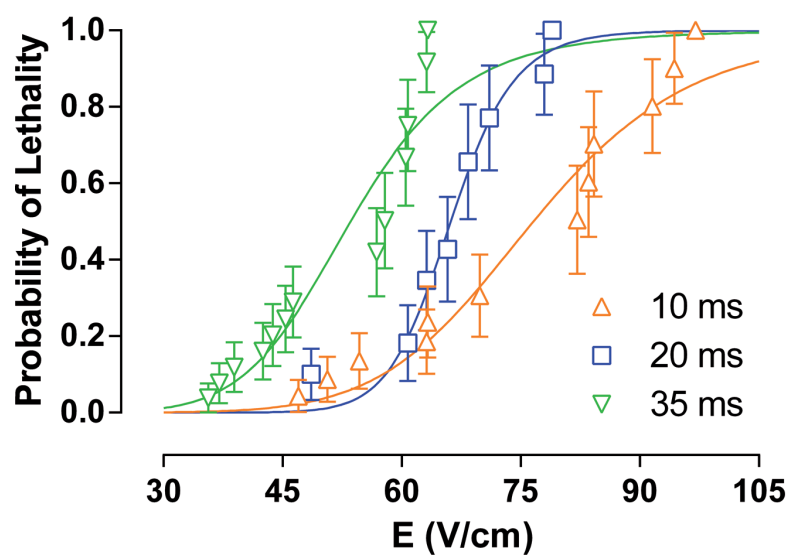

B

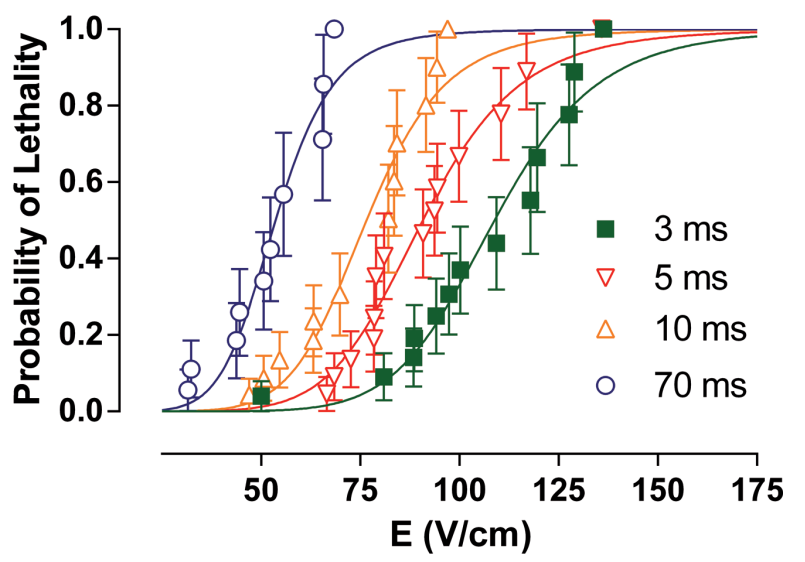

D

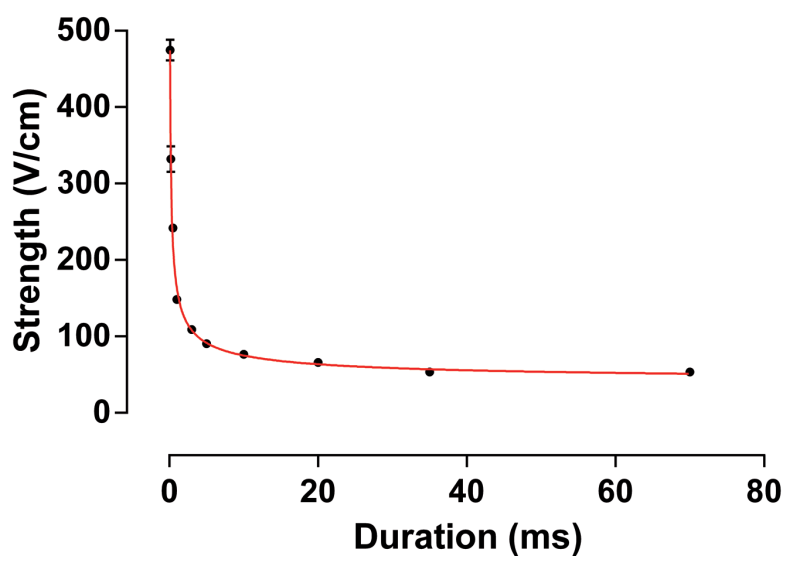

Figure 3. Lethality curves and strength-duration $(\mathrm{SxD})$ curve for lethality. A. B. C. Probability of lethality of cardiac myocytes as function of the applied electric field (E), determined for different stimulus durations. Symbols indicate means and vertical bars indicate standard errors. The fitting parameters are shown in Table 3. $\mathrm{R}^{2}>0.90$ in all cases. D. SxD curve for cardiac myocytes lethality. Data are presented as means and $95 \%$ confidence intervals. The curve was fitted by Equation $3\left(K=124.5 \pm 4.90 ; A=-0.54 \pm 0.01 ; B=39.01 \pm 3.34 ; R^{2}=0.99\right)$.

SSF curve (Figure 4D) shows a non-monotonic variation, increasing as the pulse duration decreases up to 0.5 ms where it reaches a peak that might be the best pulse duration to a less damaging stimulation. Beyond this point, $\mathrm{SSF}$ decreases as the duration is reduced. The $\left(\mathrm{E} / \mathrm{E}_{\mathrm{T}-\mathrm{SPL}}\right)_{50}$ points are not significantly deviated from the SSF curve model (Eq. $4 ; p=0.53$, Runs test) and there is also a peak of $\left(\mathrm{E} / \mathrm{E}_{\mathrm{T}-\mathrm{SPL}}\right)_{50}=38.88$ at $0.5 \mathrm{~ms}$.

\section{Discussion}

In this work we showed for the first time that the SSF curve has an optimal duration correspondent to $0.5 \mathrm{~ms}$. As expected, we observed that the higher the intensity of HEF, the higher the probability of lethality as well (Oliveira et al. 2008; Goulart et al. 2012); $n$ was different for 20 ms com- pared to the majority of the curves; however, we are unable to explain the phenomenon associated just with our current data. According to electrical stimulation models (Klee and Plonsey 1976; Kotnik et al. 1997; Ying and Henriquez 2007), greater $\mathrm{E}$ induces greater $\Delta \mathrm{V}_{\mathrm{m}}$, increasing the probability of irreversible hydrophilic pores to appear in the membrane (Tovar and Tung 1992; Wilhelm et al. 1993; Weaver and Chizmadzhev 1996). Furthermore, when the pulse duration is longer, the probability of lethality is higher for the same HEF intensity. This might be explained by increased severe electroporation probability for longer pulses (Weaver and Chizmadzhev 1996; Miklavčič et al. 2010).

Once the cell membrane is disrupted by a non-lethal HEF, a massive $\mathrm{Ca}^{2+}$ influx promotes alterations, such as protein aggregation, phosphate precipitation, proteolysis, mitochondrial dysfunction, which might lead to a delayed cell death (Krauthamer and Jones 1997; Nikolski and Efimov 2005; Case 
A

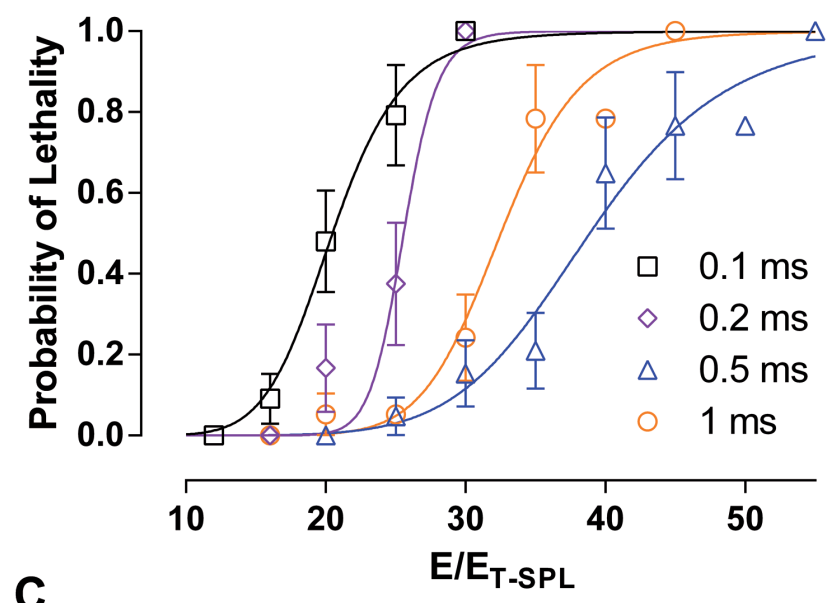

C

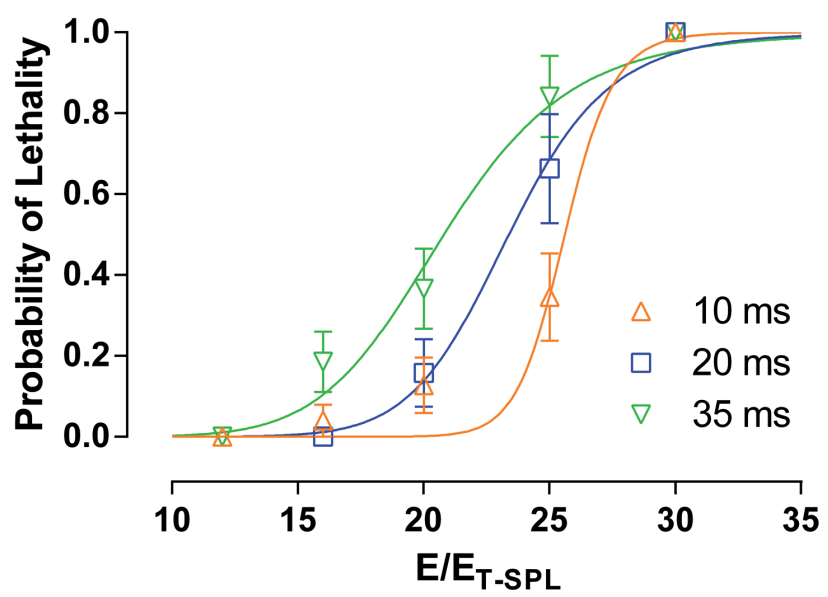

B
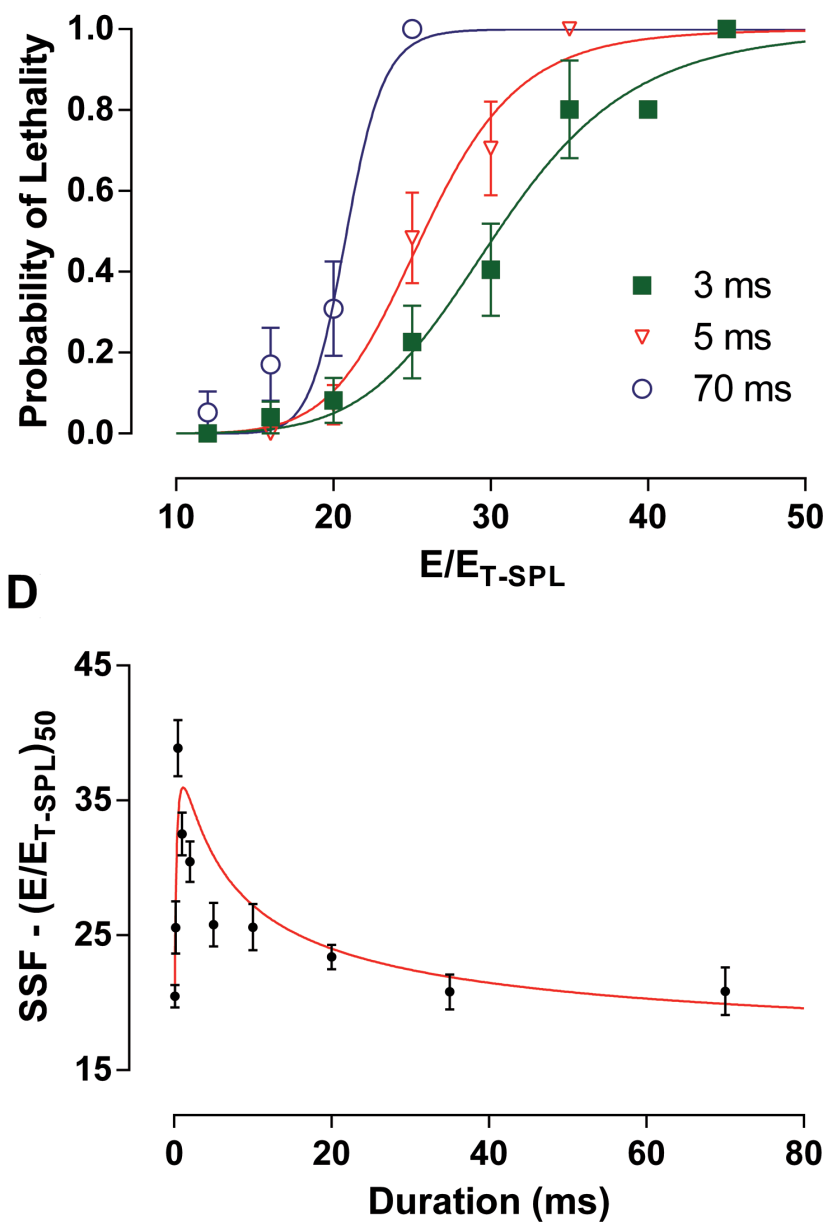

Figure 4. Normalized lethality curves and stimulation safety factor (SSF). A. B. C. Probability of lethality of cardiac myocytes as function of the ratio between the applied electric field $(\mathrm{E})$ and $\mathrm{E}$ threshold $\left(\mathrm{E}_{\mathrm{T}}\right.$, biphasic pulse) with the specific pulse length of each group ( $\mathrm{E}_{\mathrm{T}-\mathrm{SPL}}$ ). The fitting parameters are shown in Table $4 . \mathrm{R}^{2}>0.95$ in all cases. Symbols indicate means and vertical bars indicate standard errors. D. SSF (Table 4) as a function of the pulse duration, the red line was generated from Eq. 4. Symbols indicate means and vertical bars indicate $95 \%$ confidence intervals.

et al. 2007; Fedorov et al. 2008; Klauke et al. 2010). Also, $\mathrm{Ca}^{2+}$ overload may promote arrhythmias, even re-inducing ventricular fibrillation (Bassani et al. 1997; Zaugg 2004). It is unquestionable the clinical importance of long-term side-effects of defibrillator-like shocks which may reduce patient survival hours after a successful defibrillation (Tung 1996; Xie et al. 1997; Tang et al. 1999; Bunch et al. 2003; Nikolski and Efimov 2005; Fedorov et al. 2008). However, immediate myocardium shock-induced injury should not be overlooked (Sham'A et al. 2014). In fact, during defibrillation, the heart is exposed to HEF ranging from 1 to $189 \mathrm{~V} / \mathrm{cm}$ (Yabe et al. 1990) which is strong enough to cause immediate cell death (Oliveira et al. 2008; Klauke et al. 2010; Goulart et al. 2012).

We found that excitation and immediate cell death had a similar mathematical behavior when relating electric field strength to duration and that both could be fitted by the Weiss-Lapicque equation. However, excitation and immediate cell death are governed by different phenomena - excitation depends on voltage-dependent channel opening (Bers 2001) whereas immediate death is caused by irreversible electroporation (Tung 1996; Klauke et al. 2010; Miklavčič et al. 2010). Therefore, we adapted an equation that describes HEp-2 cancerous human cell death by electroporation (Krassowska et al. 2003) into our data about cell death. Krassowska et al. used a maximum duration of $16 \mathrm{~ms}$. In that case, it is inferable that the curve would tend to zero for longer durations. Our work extends to longer durations, up to $70 \mathrm{~ms}$, and shows that the curve tends to a positive asymptotic value, requiring a constant term $B$ in their equation to take into account this new tendency. The positive asymp- 
totic value is reasonable because a minimal transmembrane potential needs to be reached for electroporation (Kotnik et al. 2003). The fit using this adapted equation to the lethality curve was better than the one with the Weiss-Lapicque equation ( $p<0.0001$, extra sum-of-squares F-test).

The SSF curve displays a maximum close to $0.5 \mathrm{~ms}$, which could be used to improve the defibrillation safeness since we observed a bigger range of threshold from stimulation to lethality. Perhaps defibrillation with pulse duration of $\sim 0.5$ ms might be a better approach than $10 \mathrm{~ms}$, the typical duration clinically used (Tacker and Geddes 1996).

Some limitations must be considered in our study. We used $\mathrm{E}_{\mathrm{T}-\mathrm{SPL}}$ to calculate the intensity of HEF delivered to cell (i.e., the defibrillator-like shock intensity). The most accurate way to calculate the HEF intensity should be using $\mathrm{E}_{\mathrm{T} \text {-mono }}$ rather than $\mathrm{E}_{\mathrm{T}-\mathrm{SPL}}$. However, it was impossible to perform the whole experimental protocol using monopolar pulses, because it causes noticeable electrode polarization. As $\mathrm{E}$ estimation in perfusion chamber is unfeasible with electrode polarization, we decided to use the $\mathrm{E}_{\mathrm{T}-\mathrm{SPL}}$ to calculate the HEF intensity of defibrillator-like shocks. Even HEF pulses being monophasic and $\mathrm{E}_{\mathrm{T}-\mathrm{SPL}}$ being biphasic, our results with paired $\mathrm{E}_{\mathrm{T} \text {-mono }}$ and $\mathrm{E}_{\mathrm{T} \text {-biph }}$ excitation $\mathrm{SxD}$ curves demonstrate that they display a linearly correlated behavior. Then we considered that simplifying the protocol did not interfere considerably with the results and it was a better approach than working with an electrode polarization situation. A critical limitation in our work was the progressive increase of $\mathrm{HEF}$ as a function of $\mathrm{E}_{\mathrm{T}}$ during the lethality curve protocol. It results in different number of shocks in each cell before death. Multiple countershocks are often delivered to patients during cardiopulmonary resuscitation; however, a higher number of shocks may generate cumulative damages causing cell impairment. We observed that some non-lethal HEF are able to damage cells, sometimes promoting reversible hypercontracture with permanent cell length reduction. The number of shocks was $3-5$ in all groups, except the group that received HEF with $0.5 \mathrm{~ms}$ duration which received about 8 shocks. Thus, the cumulative effect of HEF shocks cannot be ignored, and it might even lead to an underestimated value of the peak at $0.5 \mathrm{~ms}$ in SSF curve. On the other hand, a reversible electroporation, and consequent elevation of cytosolic $\mathrm{Ca}^{2+}$, is able to activate membrane repair mechanisms, making cells more efficient at membrane pores sealing and less vulnerable to lethal effects of HEF (Steinhardt et al. 1994; Togo et al. 1999). Further works are required to fully understand the influence of different number of shocks.

Important considerations must be made if extrapolation to clinical trials is desired. A primary and most obvious discrepancy would be that our results were taken from isolated cells from rat hearts oriented longitudinally to the electric field. A whole heart contains loads of cells with dif- ferent mechanical and electrical characteristics, oriented in all directions and connected through gap-junctions, which means that each individual cell may behave quite differently in response to the electric field applied. In fact, each cell should perceive a different variation of $\mathrm{V}_{\mathrm{m}}$, not only because of cell orientation, shape and location, but also because of the generation of virtual electrodes in the tissue (Knisley et al. 1994; Roth 1995). In an experimental and simulation work done by Sambelashvili et al. (2004), the authors investigated the effects of electroporation and cell uncoupling after tissue electrical damage, arguing that both effects could work additively and interfere with virtual electrode topography. Our work considers immediate cell death, probably due to irreversible electroporation, as a major concern and does not assess reversible electroporation, or cell uncoupling. Although it is difficult to correlate our results to clinical issues, the strength duration curves from human heart excitation (Davies and Sowton 1966) and defibrillation (Gold and Shorofsky 1997) also have shown a monoexponential shape; thereby we speculate that there might be an SSF peak in whole heart in which further studies should be conducted to confirm our assumption.

Another obstacle to overcome would be to estimate how excitability and lethality would behave at physiological temperatures. Electroporation seems to have a decreasing threshold as the temperature rises (Coster and Zimmermann 1975), however, breakdown potential difference seems to remain stable within the range from room $\left(25^{\circ} \mathrm{C}\right)$ to physiological temperatures. Regarding the same influence upon stimulation, strength-duration curve shows an increment in rheobase and chronaxie with temperature decrement in ground squirrel and rat papillary preparations but no significant difference was found from room $\left(25^{\circ} \mathrm{C}\right)$ to physiological $\left(35^{\circ} \mathrm{C}\right)$ temperature (Wang et al. 1997). If both thresholds rest unchanged as temperature rises to physiological levels, we would expect minor changes on the SSF curve. However, our protocol does not allow confirming this hypothesis.

In conclusion, SSF curve might be related to stimulatory safety (i.e., the higher the SSF, the higher the stimulatory safety), therefore, we hypothesize shorter pulses are safer until a certain point. These results might help to develop further works in areas related to electropermeabilization, transfection, cell/tissue stimulation and it is possible to explore them in terms of defibrillation effectiveness.

Acknowledgements. The authors are grateful to Mr. Carlos Alberto Lourenço, Ms. Elizângela Souto Oliveira and Mr. Renato da Silva Moura for the technical support and assistance, and to Prof. Dr. José W. M. Bassani and Prof. Dr. Rosana A. Bassani for all the scientific support during the development of this work. This study was supported by CAPES (Coordination of Improvement of Higher Education Personnel, in Portuguese, scholarship to LNSP) 
and FAPESP (Foundation for Research of the State of São Paulo, in Portuguese, Proc. N 2011/51199-6). The authors thank Espaço da Escrita - Coordenadoria Geral da Universidade-UNICAMP - for the language services provided.

Conflict of interests: The authors declare that they have no conflict of interests.

\section{References}

Bassani R. A., Bassani J. W., Lipsius S. L., Bers D. M. (1997) Diastolic SR Ca efflux in atrial pacemaker cells and Caoverloaded myocytes. Am. J. Physiol. Heart Circ. Physiol. 273, H886-892

Bassani R. A., Lima K. A., Gomes P. A., Oliveira P. X., Bassani J. W. (2006): Combining stimulus direction and waveform for optimization of threshold stimulation of isolated ventricular myocytes. Physiol. Meas. 27, 851-863

http://dx.doi.org/10.1088/0967-3334/27/9/008

Bers D. M. (2001): Excitation-Contraction Coupling and Cardiac Contractile Force. Kluwer Academic Publishers, Dordrecht and Boston http://dx.doi.org/10.1007/978-94-010-0658-3

Bunch T. J., White R. D., Gersh B. J., Meverden R. A., Hodge D. O., Ballman K. V., Hammill S. C., Shen W.-K., Packer D. L. (2003): Long-term outcomes of out-of-hospital cardiac arrest after successful early defibrillation. N. Engl. J. Med. 348, 2626-2633 http://dx.doi.org/10.1056/NEJMoa023053

Case R. M., Eisner D., Gurney A., Jones O., Muallem S., Verkhratsky A. (2007): Evolution of calcium homeostasis: from birth of the first cell to an omnipresent signaling system. Cell Calcium 42, 345-350 http://dx.doi.org/10.1016/j.ceca.2007.05.001

Coster H. G. L., Zimmermann U. (1975): The mechanism of electrical breakdown in the membranes of Valonia utricularis. J. Membrane Biol. 22, 73-90 http://dx.doi.org/10.1007/BF01868164

Davies J. G., Sowton E. (1966): Electrical threshold of the human heart. British Heart Journal 28, 231-239 http://dx.doi.org/10.1136/hrt.28.2.231

Fedorov V. V., Nikolski V. P., Efimov I. R. (2008): Effect of electroporation on cardiac electrophysiology. Methods Mol. Biol. 423, 433-448 http://dx.doi.org/10.1007/978-1-59745-194-9_34

Gold M. R., Shorofsky S. R. (1997): Strength-duration relationship for human transvenous defibrillation. Circulation 96, 3517-3520 http://dx.doi.org/10.1161/01.CIR.96.10.3517

Goulart J. T., Oliveira P. X., Bassani J. W. M., Bassani R. A. (2012): The influence of cell dimensions on the vulnerability of ventricular myocytes to lethal injury by high-intensity electrical fields. Rev. Bras. Eng. Bioméd. 28, 337-345 http://dx.doi.org/10.4322/rbeb.2012.040

Ivorra A. (2010): Tissue electroporation as a bioelectric phenomenon: basic concepts. In: Irreversible Electroporation. (Ed. B. Rubinsky), pp. 23-61, Springer Berlin, Heidelberg http://dx.doi.org/10.1007/978-3-642-05420-4_2
Jones J. L., Lepeschkin E., Jones R. E., Rush S. (1978): Response of cultured myocardial cells to countershock-type electric field stimulation. Am. J. Physiol. Heart Circ. Physiol. 235, H214-222

Jones J. L., Jones R. E. (1980): Postshock arrhythmias - a possible cause of unsuccessful defibrillation. Critical Care Medicine 8, 167-171 http://dx.doi.org/10.1097/00003246-198003000-00016

Jones J. L., Jones R. E. (1984): Decreased defibrillator-induced dysfunction with biphasic rectangular waveforms. Am. J. Physiol. Heart Circ. Physiol. 247, H792-796

Jones J. L., Jones R. E., Balasky G. (1987): Microlesion formation in myocardial cells by high-intensity electric field stimulation. Am. J. Physiol. Heart Circ. Physiol. 253, H480-486

Kinosita Jr. K., Ashikawa I., Saita N., Yoshimura H., Itoh H., Nagayama K., Ikegami A. (1988): Electroporation of cell membrane visualized under a pulsed-laser fluorescence microscope. Biophys. J. 53, 1015-1019 http://dx.doi.org/10.1016/S0006-3495(88)83181-3

Klauke N., Smith G., Cooper J. M. (2010): Regional electroporation of single cardiac myocytes in a focused electric field. Anal. Chem. 82, 585-592 http://dx.doi.org/10.1021/ac901886j

Klee M., Plonsey R. (1976): Stimulation of spheroidal cells-the role of cell shape. IEEE Trans. Biomed. Eng. 23, 347-354 http://dx.doi.org/10.1109/TBME.1976.324597

Kleinbaum D. G. (1996): Survival Analysis: A Self-Learning Text. Springer-Verlag, New York http://dx.doi.org/10.1007/978-1-4757-2555-1

Knisley S. B., Hill B. C., Ideker R. E. (1994): Virtual electrode effects in myocardial fibers. Biophys. J. 66, 719-728 http://dx.doi.org/10.1016/S0006-3495(94)80846-X

Kotnik T., Bobanović F., Miklavčič D. (1997): Sensitivity of transmembrane voltage induced by applied electric fields - a theoretical analysis. Bioelectrochem. Bioenerg. 43, 285-291 http://dx.doi.org/10.1016/S0302-4598(97)00023-8

Kotnik T., Pucihar G., Rebersek M., Miklavčič D., Mir L. M. (2003): Role of pulse shape in cell membrane electropermeabilization. Biochim. Biophys. Acta 1614, 193-200 http://dx.doi.org/10.1016/S0005-2736(03)00173-1

Krassowska W., Nanda G. S., Austin M. B., Dev S. B., Rabussay D. P. (2003): Viability of cancer cells exposed to pulsed electric fields: the role of pulse charge. Ann. Biomed. Eng. 31, 80-90 http://dx.doi.org/10.1114/1.1531634

Krauthamer V., Jones J. L. (1997): Calcium dynamics in cultured heart cells exposed to defibrillator-type electric shocks. Life Sci. 60, 1977-1985

http://dx.doi.org/10.1016/S0024-3205(97)00162-8

Louch W. E., Sheeha K. A., Wolska B. M. (2011): Methods in cardiomyocyte isolation, culture, and gene transfer. J. Mol. Cell. Cardiol. 51, 288-298 http://dx.doi.org/10.1016/j.yjmcc.2011.06.012

Miklavčič D., Pucihar G., Lebar A. M., Krmelj J., Towhidi L. (2010): The pulse intensity duration dependency for cell membrane electroporation. In: Advanced Electroporation Techniques in Biology and Medicine. (Eds. A. G. Pakhomov, D. Miklavčič and M. S. Markov), pp. 239-251, Crc Press, London

Nikolski V. P., Efimov I. R. (2005): Electroporation of the heart. Europace (London) 7, S146-154 
http://dx.doi.org/10.1016/j.eupc.2005.04.011

Oliveira P. X. de, Bassani R. A., Bassani J. W. (2008): Lethal effect of electric fields on isolated ventricular myocytes. IEEE Trans. Biomed. Eng. 55, 2635-2642 http://dx.doi.org/10.1109/TBME.2008.2001135

Peleška B., Blažek Z., Prábl M., Sládková E., Roth Z. (1963): Cardiac arrhythmias following condenser discharges and their dependence upon strength of current and phases of cardiac cycle. Circulation Research 13, 21-32 http://dx.doi.org/10.1161/01.RES.13.1.21

Penna L. B., Bassani R. A. (2010): Increased spontaneous activity and reduced inotropic response to catecholamines in ventricular myocytes from footshock-stressed rats. Stress 13, 73-82 http://dx.doi.org/10.3109/10253890902951778

Reilly J. P., Alan M. D., James C. (2009): Dosimetry considerations for electrical stun devices. Phys. Med. Biol. 54, 1319-1335 http://dx.doi.org/10.1088/0031-9155/54/5/015

Roger V. L., Go A. S., Lloyd-Jones D. M., Benjamin E. J., Berry J. D., Borden W. B., Bravata D. M., Dai S., Ford E. S., Fox C. S., et al. (2012): Heart disease and stroke statistics-2012 update: a report from the American Heart Association. Circulation 125, e2-220 http://dx.doi.org/10.1161/CIR.0b013e31823ac046

Roth B. J. (1995): A mathematical model of make and break electrical stimulation of cardiac tissue by a unipolar anode or cathode. IEEE Trans. Biomed. Eng. 42, 1174-1184 http://dx.doi.org/10.1109/10.476124

Sambelashvili A. T., Nikolski V. P., Efimov I. R. (2004): Virtual electrode theory explains pacing threshold increase caused by cardiac tissue damage. Am. J. Physiol. Heart Circ. Physiol. 286, H2183-2194 http://dx.doi.org/10.1152/ajpheart.00637.2003

Sham'A R. A., Nery P., Sadek M., Yung D., Redpath C., Perrin M., Sarak B., Birnie D. (2014): Myocardial injury secondary to icd shocks: insights from patients with lead fracture. Pacing Clin. Electrophysiol. 37, 237-241 http://dx.doi.org/10.1111/pace.12263

Steinhardt R., Bi G., Alderton J. (1994): Cell membrane resealing by a vesicular mechanism similar to neurotransmitter release. Science 263, 390-393 http://dx.doi.org/10.1126/science.7904084

Tacker W. A., Geddes L. A. (1996): The laws of electrical stimulation of cardiac tissue. Proc. IEEE Inst. Electr. Electron. Eng. 84, 355-365 http://dx.doi.org/10.1109/5.486739

Tang W., Weil M. H., Sun S., Yamaguchi H., Povoas H. P., Pernat A. M., Bisera J. (1999): The effects of biphasic and conventional monophasic defibrillation on postresuscitation myocardial function. J. Am. Coll. Cardiol. 34, 815-822 http://dx.doi.org/10.1016/S0735-1097(99)00270-3

Togo T., Alderton J. M., Bi G. Q., Steinhardt R. A. (1999): The mechanism of facilitated cell membrane resealing. J. Cell. Sci. 112, 719-731

Tovar O., Tung L. (1992): Electroporation and recovery of cardiac cell membrane with rectangular voltage pulses. Am. J. Physiol. 263, H1128-1136

Tung L. (1996): Detrimental effects of electrical fields on cardiac muscle. Proceedings of the IEEE 84, 366-378 http://dx.doi.org/10.1109/5.486740

Wang S., Cao H., Zhou Z (1997): Temperature dependence of the myocardial excitability of ground squirrel and rat. Journal of Thermal Biology 22, 195-199 http://dx.doi.org/10.1016/S0306-4565(97)00010-7

Weaver J. C. (1994): Molecular basis for cell membrane electroporation. Ann. N. Y. Acad. Sci. 720, 141-152 http://dx.doi.org/10.1111/j.1749-6632.1994.tb30442.x

Weaver J. C., Chizmadzhev Y. A. (1996): Theory of electroporation: a review. Bioelectrochem. Bioenerg. 41, 135-160 http://dx.doi.org/10.1016/S0302-4598(96)05062-3

Wilhelm C., Winterhalter M., Zimmermann U., Benz R. (1993): Kinetics of pore size during irreversible aelectrical breakdown of lipid bilayer membranes. Biophys. J. 64, 121-128 http://dx.doi.org/10.1016/S0006-3495(93)81346-8

Xie J., Weil M. H., Sun S., Tang W., Sato Y., Jin X., Bisera J. (1997): High-energy defibrillation increases the severity of postresuscitation myocardial dysfunction. Circulation 96, 683-688 http://dx.doi.org/10.1161/01.CIR.96.2.683

Yabe S., Smith W. M., Daubert J. P., Wolf P. D., Rollins D. L., Ideker R. E. (1990): Conduction disturbances caused by high current density electric fields. Circ. Res. 66, 1190-1203 http://dx.doi.org/10.1161/01.RES.66.5.1190

Ying W., Henriquez C. S. (2007): Hybrid finite element method for describing the electrical response of biological cells to applied fields. IEEE Trans. Biomed. Eng. 54, 611-620 http://dx.doi.org/10.1109/TBME.2006.889172

Zaugg C. E. (2004): Current concepts on ventricular fibrillation: a vicious circle of cardiomyocyte calcium overload in the initiation, maintenance, and termination of ventricular fibrillation. Indian Pacing Electrophysiol. J. 4, 85-92

Received: March 16, 2015

Final version accepted: September 8, 2015

First published online: February 2, 2016 